\title{
Trendy ve výzkumu matematického vyučování
}

\author{
Trends in research in mathematics education
}

Alena Hošpesová

\begin{abstract}
Abstrakt: Na základě studia literatury jsou v př́ispěvku formulovány trendy výzkumu v didaktice matematiky ve světě v posledních dvaceti letech: výzkum se stává komplexnějším; stále více se prosazuje snaha po formulování teoretických východisek; sílí zájem politických reprezentací. Jsou ukázány převládající směry ve výzkumu matematického vyučování.
\end{abstract}

Klíčová slova: trendy ve výzkumu, didaktika matematiky

\begin{abstract}
In the contribution the trends in research on didactics of mathematics in last twenty years are formulated on the basis of the study of relevant literature: research becomes more complex; the effort to formulate clear theoretical background strengths; political representation is more interested in results. Prevalent research directions in research of mathematics education are shown.
\end{abstract}

Keywords: trends in research, didactics of mathematics

\section{Proč se zabýváme výzkumem v didaktice matematiky?}

Odpovědět na tuto otázku můžeme s ohledem na použití výsledků výzkumu v praxi vcelku jednoduše: stále se setkáváme se žáky/studenty, kteří se ve školní matematice naučí méně, než potřebují oni sami i společnost. Věříme, že je možné vytvořit lepší podmínky pro jejich učení, at' už ve školním vyučování, či mimo ně. Cílem výzkumu v didaktice matematiky je zjistit, jak plánovat, řídit, uskutečňovat matematické vyučování, aby se každý žák učil matematiku optimálně, podle svých potřeb, přání a potencialit.

Badatelská komunita ale přináší v každé chvíli takové množství výsledků, že je obtížné je sledovat a orientovat se v nich. Zájemcům mohou pomoci např́íklad dvě shrnující publikace (Grouws, 1992; Lester, 2007), kde je možné získat přehled o vývoji v určité oblasti i o badatelích, kteří zde pracují. Ze studia těchto publikací také vychází tento příspěvek.

\section{Trendy výzkumu v posledních dvaceti letech}

Didaktika matematiky zaznamenala značný rozvoj zejména od 60. let minulého století. Zabývala se především tím, jak se mají žáci/studenti učit určité téma, a snažila se vytvářet teorie, jak probíhá učení se konkrétním učebním obsahům (např. jak se vytváŕí pojem číslo, jak se formuje myšlení v geometrii). V posledních dvaceti letech si badatelé uvědomili, že zkoumané jevy jsou podstatně komplexnější; vyučování a učení není nadále vnímáno jako funkce charakteristik žáka 
a vědomostí učitele. Perspektivy se rozšiřují a hledají se další proměnné, které mají vliv na vzdělávání v matematice, např. vzdělání učitele, vliv způsobu hodnocení, použití informačních a komunikačních technologií. Také se prosazují témata, která jsou spíše psychologická, pedagogická nebo sociologická.

V posledním období celá oblast didaktiky matematiky pocituje nebývalý zájem politiků o výsledky výzkumu. To by jistě bylo potěšující, kdyby cílem bylo vybavit jednotlivce takovými prerekvisitami, které jim pomohou vyrovnat se se životem v jeho různých sférách. Bohužel se jeví, že jde spíše o povzbuzení technologického a socio-ekonomického rozvoje společnosti $\mathrm{s}$ cílem uspět $\mathrm{v}$ soutěži s jinými.

$\mathrm{V}$ posledních dvaceti letech je také možné pozorovat tlak na teoretické ukotvení vědeckého bádání. Badatelé stále častěji věnují úsilí vymezeni teoretického rámce, ve kterém uskutečnili svůj výzkum. Teoretickým rámcem je obvykle míněn soubor teoretických konstruktů (pojmů, předpokladů) více méně definovaných, se kterými se operuje, a také soubor preferovaných metod, které jsou pro výzkum považovány za vhodné. Není překvapující, že autoři dost často prosazují teoretický rámec, na jehož formulování se podíleli. I když nejsou komponenty teoretického rámce explicitně uváděny, jsou v př́stupu př́tomné. Jmenujme např. teorie: didaktických situací (Brousseau, 1997), pojmových polí (Vergnaud, 2009), socio-matematických norem (Cobb \& Yackel, 1996), učitelovy znalosti matematiky pro výuku (Ball, Lubienski, \& Mewborn, 2001).

Zdá se, že mezinárodní komunita „touži“ po vytvoření jednotné teorie didaktiky matematiky. To ale zdaleka není obzoru. Bohužel se ukazuje, že často nepanuje shoda ani v tom, jaký teoretický rámec je přijatelný pro studium určitého tématu. Př́ikladem může být zkoumání řešení problémů, nebo důkazů a dokazování.

\section{Reflexe stavu výzkumu matematického vzdělávání}

Nejsilnější současné trendy výzkumu v didaktice matematiky je možné odhadnout na základě témat plenárních přednášek a názvů pracovních skupin na mezinárodních konferencích (např. sedmý Congress of the European Society for Research in Mathematics Education nabízel 17 pracovních skupin, konference PME - International Group for the Psychology of Mathematics Education - nabízí diskusní skupiny, tématické skupiny, výzkumná fóra). Niss (2007, s. 1300 a dále) formuluje následující seznam zkoumaných otázek: Proč se má učit matematika? Pro koho? Co to znamená umět matematiku? Jak probíhá učení se matematice? Jak učit matematiku tak, aby bylo dosaženo optimálních výsledků žáků? Jaká jsou přesvědčení studentů, jejich vztah $\mathrm{k}$ matematice, motivace? Jak hodnotit? Jaké kompetence má mít učitel matematiky?

Zabývejme se některými oblastmi podrobněji.

\subsection{Proč učit matematiku?}

Tyto otázky nemusí být předmětem výzkumu samy o sobě. Dotýká se jich však svým způsobem každý badatel. Didaktici matematiky přirozeně sdílejí názor, že každý člověk má mít nějaké matematické vzdělání. Zdaleka však nepanuje shoda $\mathrm{v}$ tom, jakou matematiku potřebují různé skupiny lidí. Např. PME 34 v roce 2010 se zaměřilo svým tématem ,mathematics in different 
settings“ právě na to, jaká matematika je potřebná pro určitá zaměstnání (mathematics for a workplace).

S tím souvisí i pojem etnomatematika, který zavedl D'Ambrosio (1984) a nastartoval debatu o souvislostech mezi matematickým vzděláváním a kulturou. Velký zájem pak vzbudily výzkumy početních technik lidí bez systematického matematického vzdělání, např. zkoumání početních technik na trzích na Bali, či účetnictví pouličních gangů mladistvých, kteří na křižovatkách v Rio de Janeiru prodávají vodu nebo noviny (Nunes, 1992).

\subsection{Co to znamená umět matematiku?}

Od 60. let byl učiněn velký pokrok v porozumění tomu, jak se různé skupiny učících se zmocňují určitých matematických témat. Zejména se to týkalo elementární matematiky. Mnohem méně výzkumných výsledků se ale zabývá diskrétní matematikou, analýzou, abstraktní algebrou a geometrií.

V poslední době se pozornost zaměřuje spíše na to, jak se pochopení určitého tématu vztahuje k pochopení tématu jiného a na analýzu obecně formulovaných kompetencí, napřr. kompetence matematického myšlení, řešení matematických problémů, modelování, uvažování, použivání matematických reprezentací, symbolů a formalismů, komunikační. Takto formulované kompetence byly využity jako teoretický základ pro mezinárodní srovnávací studie (OECD, PISA).

\subsection{Jak učit matematiku tak, aby bylo dosaženo optimálních výsledků žáků/studentů?}

Značná část výzkumu v didaktice matematiky obsahuje návrhy podněcujících činností pro žáky/studenty a popis a analýzu výukových experimentů. Metodologicky je obtížné dokumentovat, že získané výsledky (např. posuny v učení žáků) opravdu souvisí s daným vyučováním a ne s jinými proměnnými. Potvrzuje se snad jen to, že žáci/studenti mají být angažováni v činnostech, ve kterých musejí zápasit s důležitými matematickými myšlenkami a spolupracovat přitom mezi sebou. Pro badatele je ovšem obtížné vybalancovat testovaná výuková prostředí tak, aby se výzvy, které pro žáky/studenty připravili, nezměnily v nepřekonatelné překážky.

\subsection{Jak učit matematiku tak, aby bylo dosaženo optimálních výsledků žáků/studentů?}

V uplynulém období šlo především o výzkum implementace technologií (kalkulaček, počítačů, softwaru) do vyučování. Bylo dosaženo značného pokroku ve zkoumání toho, jak technologie mohou podpořit učení, zejména co se týče reprezentací matematický objektů, jevů a procesů. Zároveň bylo ale konstatováno, že technologie mohou mít i negativní vliv. Úspěch závisí téměř zcela na učiteli. Nadále platí, že potřebujeme získat hluboký vhled do toho, jak vytvářet prostředí pro učení s ICT; technologie nemůže být nadále považována za prostředek výuky, přivažek. Technologie zcela mění to, jak je matematika chápána a jak se v ní pracuje.

Velký progres byl učiněn v charakteristice a pochopení toho, co se děje ve školní třídě a v praxi vyučování. Jsme ale daleko od toho, kdy budeme schopni navrhnout a použít takové vyučování, které garantovaně povede k optimálním výsledkům vyučování všech žáků, které učíme. Nejde jen 
o problémy s prokazováním efektu vyučování. Zdá se, že vždy bude existovat množství žáků, kteří jsou v matematice slabí.

\subsection{Jaké kompetence má mít učitel matematiky?}

Posledních deset let by mohlo být označeno jako „éra učitele“. V návaznosti na Shulmanův koncept pedagogické znalosti obsahu jsou zkoumány otázky jako např. vytváření a kultivace této znalosti v př́ipravě učitelů (postgraduální a pregraduální), proces profesionalizace učitele, vliv učitelova přesvědčení o žácích a jejich možnostech učit se. Nicméně se v poslední době ozývají hlasy, že není možné ,ze všeho vinit učitele“ a pozornost se obrací k dalším souvislostem.

\section{Kam směřuje výzkum v didaktice matematiky?}

Přes množství výzkumných výsledků v oblasti se badatelé stále zabývají tím, zda má výzkum matematického vzdělávání jasnou identitu. Můžeme říci, že ano, ale vždy asi budou existovat různá směřování:

- $\mathrm{k}$ výzkumu zaměřenému na identifikaci a vysvětlování jevů a procesů,

- k navrhování výuky pro určité skupiny žáků/studentů,

- $\mathrm{k}$ cíli vybavit jedince kompetencemi, které mu pomohou lépe se vyrovnat s různými výzvami života.

Není také jasná odpověd' na otázku, zda didaktika matematiky patř́ k sociálním, humanitním nebo př́rodním vědám. Spíše je jeví, že patří úplně jinam a toto místo je třeba definovat jak pro didaktiku matematiky, tak i pro ostatní oborové didaktiky.

Jaký bude další vývoj? Určitě se posílí tendence jasněji definovat teoretický základ výzkumu a seriózněji hledět na metodologické otázky. Mohl by to být úkol pro ICMI (International Commission on Mathematical Instruction) a jí ustanovenou skupinu expertů.

Také je třeba, aby každý nový výzkum vycházel ze studia předchozích výsledků. Vzhledem $\mathrm{k}$ rostoucímu počtu publikací v oblasti se zdá, že nemáme dostatečný přehled o tom, co jsme už věděli. Tím se přirozeně značně ochuzujeme.

Shrneme-li předchozí, didaktika matematiky je disciplínou, která nabízí množství výzkumných otázek, které mohou zájemci řešit ve velké, pracovité a vcelku přátelské mezinárodní komunitě.

\section{Literatura}

Ball, D.L., Lubienski, S., \& Mewborn, D. (2001). Research on teaching mathematics: the unsolved problem on teachers' knowledge of mathematics. In V. Richardson (Ed.), Handbook of research on teaching (4th edition) (pp. 433-455). New York: Macmillan.

Brousseau, G. (1997). Theory of didactical situations in mathematics 1970-1990. Dordrecht: Kluwer Academic Publishers.

CERME 7 (2011). Dostupné z http://www.cerme7.univ.rzeszow.pl/index.php

Cobb, P., \& Yackel, E. (1996). Sociomathematical norms, argumentation, and autonomy in mathematics. Journal for Research in Mathematics Education, 22, 390-408.

D'Ambrosio, U. (1985). Ethnomathematics and its place in the history and pedagogy of mathematics. For the Learning of Mathematics, 5(1), 44-48. 
Grouws, D.A. (Ed.) (1992). Handbook of research on mathematics teaching and learning. Reston: National Council of Teachers of Mathematics.

Lester, F.K., Jr. (Ed.) (2007). Second handbook of research on mathematics teaching and learning. Charlotte, NC: Information Age Publishing.

Niss, M. (2007). Reflections on the State and Trends in Research on Mathematics Teaching and Learning. In F. K.Lester, Jr. (Ed.), Second handbook of research on mathematics teaching and learning (pp. 1293-1312). Charlotte, NC: Information Age Publishing.

Nunes, T. (1992). Ethnomathematics and everyday cognition. In A. D. Grouws (Ed.), Handbook of research in mathematics teaching and learning (pp. 557-574). New York: Macmillan Publishing Company.

Vergnaud, G. (2009). The theory of conceptual fields. Human Development, 52, 83-94.

\section{Kontakty}

doc. PhDr. Alena Hošpesová, Ph.D.

Jihočeská univerzita v Českých Budějovicích

Pedagogická fakulta, Katedra pedagogiky a psychologie

Jeronýmova 10, 37115 České Budějovice

e-mail: hospes@pf.jcu.cz

\section{Bibliografické údaje}

Hošpesová, A. (2011). Význam kvalitativních metod v pilotní studii kvantitativního výzkumu. In T. Janík, P. Knecht, \& S. Šebestová (Eds.), Smíšený design v pedagogickém výzkumu: Sborník př́spěvků z 19.

výroční konference České asociace pedagogického výzkumu (s. 393-397). Brno: Masarykova univerzita.

Dostupné z: http://www.ped.muni.cz/capv2011/sbornikprispevku/hospesova.pdf

doi: $10.5817 /$ PdF.P210-CAPV-2012-14 